\title{
NOTES ON SOME CULTIVATED TREES AND SHRUBS, II*
}

\author{
Alfred Rehder
}

Juglans nigra L. f. laciniata, f. nova.

Juglans nigra laciniata J. Hershey, Price list Nut Tree Nurseries p. 4 [1937] "Cut Leaf Black Walnut," cum descr. angl.; p. 6 [1940] "J. Laciniata"; p. 8 [1941] “J. Nigra Laciniata," nom.

A typo speciei differt foliis bipinnatis, foliolis primi ordinis pinnatis, pinnulis utrinque 5-8 oblongo-lanceolatis vel lanceolatis serratis vel interdum plus minusve raro fere ad medium pinnatifidis basi decurrentibus, pinnula terminali pinnatifida vel plus minusve serrata.

Cultivated specrmens: Arnold Arboretum, no. 309-41, E. J. Palmer, Sept. 8, 1944 (plant received in 1941 from H. F. Stoke, Roanoke, Va.).

A very distinct form with bipinnate leaves finely dissected into lanceolate to linear-lanceolate and serrate to pinnatifid leaflets $1-3.5 \mathrm{~cm}$. long and 4-i1 mm. wide. In the shape of its foliage and in general appearance this form resembles somewhat Rhus typhina f. dissecta Rehder, but it is more finely dissected and more graceful; the tree certainly merits attention as a highly ornamental form.

With the exception of the laciniate form of the English Walnut, Juglans regia f. laciniata (Jacques) Schneider, no other form with lacinate leaflets was known in the whole family until the form of $J$. nigra described above was raised. The cut-leaved form of the English Walnut, from which $J$. regia f. heterophylla (Jacques) Schneider differs but little, is distinctly inferior as an ornamental plant to the cut-leaved Black Walnut, having a rather coarse, very irregularly shaped foliage, and moreover being more tender.

According to information kindly furnished by Mr. J. W. Hershey, the owner of the Nut Tree Nurseries at Downingtown, Pa., about thirty plants of this form were found in 1926 at the State Nursery at Milton, Pa., among seedlings raised from seed collected from normal Black Walnut trees in Buffalo Valley, east of the State Nursery. Unfortunately most of the seedlings got lost, but Mr. Hershey obtained one plant and, recognizing its ornamental value, propagated it so that he was able in 1937 to offer it for sale. The Arnold Arboretum received in 1941 a plant of this form from Mr. H. F. Stoke of Roanoke, Va., with the statement that it originated in Pennsylvania; this was probably obtained from the same source as Mr. Hershey's plant.

Juglans cordiformis Maxim. var. ailantifolia (Carr.), comb. nov.

Juglans Sieboldiana Maximowicz in Bull. Acad. Sci. St. Pétersb. 18: 61 (in Mél. Biol. 8: 63) (1873). - Miyabe \& Kudo, Icon. For. Trees Hokk. 65, t.20 (1922). - Non Goeppert (1854), fossil.

\footnotetext{
* For no. I see p. 67 of this volume.
} 
Juglans ailantifolia Carrière in Rev. Hort. 1878:414, fig. 85-86 (1878). - Little in Jour. Washington Acad. Sci. 33: 132 (1943).

Juglans macrophylla Carrière in op. cit. 415 (1878).

Juglans japonica Hort. ex Lavallée, Arb. Segrez. Icon. 1 [1880], pro syn.

Juglans ailantifolia var. cordiformis (Maxim.) Rehder in Jour. Arnold Arb. 26:68 (1945).

When Little in 1943 (1. c.) drew attention to the fact that J. Sieboldiana Maxim. was antedated by J. Sieboldiana Goeppert of 1854 and took up the name J. ailantifolia Carr. for the species, I accepted his disposition and, considering $J$. cordiformis Maxim. a variety of $J$. Sieboldiana, I published the combination $J$. ailantifolia var. cordiformis, overlooking the fact that $J$. cordiformis Maxim. of 1873 has priority over J. ailantifolia Carr. of 1878 and should have been taken up when J. Sieboldiana Maxim. was invalidated by the older homonym of Goeppert. As there can be little doubt that J. cordiformis Maxim. and J. Sieboldiana Maxim. are conspecific and represent only variations in the shape of the fruit, the name $J$. cordiformis has to be taken up when J. Sieboldiana is rejected, which makes necessary the new combination proposed above. If, however, J. cordiformis and $J$. Sieboldiana Maxim. should be considered distinct species, the latter would become $J$. ailantifolia Carr.

Ulmus parvifolia Jacq. f. pendens, f. nova.

A typo recedit ramis elongatis laxe pendulis.

Cultivated in California: City Park, Covina, Los Angeles Co., southwest corner of 4th Street and San Bernardino Road, tree with trunk 3' 9" in circumference, with the head 50' across, coll. C. R. Tower, Oct. 1944 (TYPE in herb. Arnold Arb. with photo. of habit); same locality, coll. C. R. Tower, Sept. 1944 (in herb. Arnold Arb.) ; John Galvin Park, Ontario, San Bernardino Co., coll. C. R. Tower, Sept. 1944, with photo. of habit showing a wide-spreading tree with somewhat less pendulous branches than the type tree (in herb. Arnold Arb.). There are also photographs in the collection of the Arnold Arboretum of this form from North Clementine St., Anaheim, Orange Co., and from the Roy F. Wilcox Nursery in Montebello, near Los Angeles.

The bark of the trunk and larger limbs is rather thin and scaly, the scales, when shedding, exposing a smooth lenticellate pale reddish layer of bark. The leaves are subcoriaceous, oblong-lanceolate, $3.5-5 \mathrm{~cm}$. long and 9-20 $\mathrm{mm}$. broad, acute or acuminate, unequal at the base, cuneate on one side and subcordate to rounded on the other. The photographs listed above show trees with a large spreading head to fifty feet wide or more, more or less flattened at the top without upright or ascending leaders, but with long and slender pendulous branches and branchlets.

This pendulous form raised in California (together with the typical form from seed received about twenty-five years ago from China) seems to be an unusual form in China, for the several photographs in our collection of $U$. parvifolia, taken in different parts of China, show trees of upright habit except in a photograph of trees taken in the grounds of the Temple of Heaven near Peking, which shows rather wide-spreading but not pendulous branches.

The epithet "pendens" has been chosen for this form to avoid confusion with Ulmus parvifolia pendula Hort. ex Dippel, Handb. Laubh. 2: 27 
(1892), pro syn., a name which apparently had been used in nursery catalogues before Dippel cited it as a synonym of a form of $U$. pumila L.

Clematis triternata DC. f. rubro-marginata (Jouin), comb. nov.

Clematis rubro-marginata Jouin in Mitt. Deutsch. Dendr. Ges. 1907(16) : 236 (1907).

Clematis Flammula var. rubro-marginata Cripps ex Jouin, l. c. (1907), pro syn.

Clematis violacea var. rubro-marginata Rehder in Jour. Arnold Arb. 1: 195 (1920);

Man. Cult. Trees Shrubs, ed. 2, 217 (1940).

According to Graebner f. in Ascherson \& Graebner, Syn. Mitteleur. Fl. 5,3: 65 (1935), C. triternata DC. [1817] is identical with $C$. violacea A. DC. (1845), which makes necessary the transfer proposed above.

$\times$ Spiraea Bumalda Burvenich f. pruhoniciana (Kriechb.), Comb. nov.

$\times$ Spiraea pruhoniciana Kriechbaum in Gartenschönh. 6: 38 (1925) "S. japonica ovalifolia $\times$ Bumalda "Anthony Waterer," nom. subnud. - Zeman ex Schneider in Silva Tarouca \& Schneider, Uns. Freil.-Laubgeh. ed. 3, 433 (1931).

Spiraea pruhoniciana, being a hybrid between the same species as $S$. Bumalda $(S$. japonica $\times$ albiflora $)$, though between different varieties or forms, cannot be classed under a separate binomial, but falls into the group of hybrids between $S$. japonica and S. albiflora.

Sorbus Aria f. longifolia (Pers.), comb. nov.

Crataegus Aria $\beta$. foliis oblongis Lamarck, Encycl. Méth. Bot. 1: 82 (1783). — Poiret in Duhamel, Traité Arb. Arbust. France, éd. augm. [Nouv. Duhamel] 4: 129, t. 34 [1809] "C. Aria" in tab.

Pyrus Aria $\beta$. longifolia Persoon, Syn. Pl. 2: 38 [1806].

Pyrus edulis Willdenow, Enum. Pl. Hort. Berol. 527 (1809).

?Pyrus Aria $\beta$. acutifolia De Candolle, Prodr. 2: 636 (1825).

Crataegus longifolia "Duham. ed. nov. 4. t.34" [1809] ex De Candolle, l. c. (1825), pro syn.

Aria edulis Roemer, Fam. Nat. Reg. Veg. Syn. 3: 124 (1847).

Sorbus edulis K. Koch, Dendr. 1: 195 (1869).

Sorbus Aria var. edulis Wenzig in Linnaea, 38:54 (1874). - Schneider, Ill. Handb. Laubh. 1: 687, fig. 377h-i (1906). - Rehder, Man. Cult. Trees Shrubs. ed. 2, 380 (1940)

Hahnia Aria f. [letter] edulis Dippel, Handb. Laubh. 3: 375 (1893).

Hahnia Aria i. angustifolia Dippel, op. cit. 376 (1893), vix Pyrus Aria angustifolia Lindley (1827).

Sorbus longifolia Hedlund in Svenska Vetensk.-Akad. Handl. 35,1:82 (Monog. Sorbus) (1901).

Pirus Aria A. I. a. edulis Ascherson \& Graebner, Syn. Mitteleur. Fl. 6,2: 95 (1906).

If the two slightly differing forms with the epithet "longifolia" and those with the epithet "edulis" are united as is done, apparently with good reason, by Hedlund and by Ascherson \& Graebner, the epithet of Persoon's name as the oldest will have to be accepted and makes necessary the new combination proposed above.

Rosa centifolia f. Andrewsii, nom. nov.

Rosa muscosa simplex Andrews, Roses, 1: $t$. [58] [1810]. - Seringe, Mus. Helv. Hist. Nat. 1: 18 [1818].

Rosa muscosa (Muscosa simplex) Thory in Redouté, Roses, $1: 39, t$. (1817).

This rose, the single-flowered form of the Moss Rose, was raised in the garden of the Countess de Vanda at Bayswater, England, and flowered there first in 1807, according to Miss Willmott's Genus Rosa (2:347 [1912]). 
It seems at present rare in gardens, and in our herbarium we have only a single specimen of this form from the garden of John Robinson, Salem, Mass., collected in 1889.

Rosa Koehneana $(R$. carolina $\times$ rugosa $)$, nom. nov.

Rosa humilis $\times$ rugosa Koehne, Deutsche Dendr. 294 (1893), sine descr. - R. Keller in Ascherson \& Graebner, Syn. Mitteleur. Fl. 6,1:308 (1902), sine descr.Willmott, Gen. Rosa, 1: 203, t. (fl.), t. (fr.) [1911].

Rosa rugosa $\times$ carolina Rehder, Man. Cult. Trees Shrubs, 442 (1927); non Graebner $(1902)=R$. Spaethiana Graebn. [R. palustris $\times$ rugosa].

As almost all of the hybrids of $R$. rugosa have received binary names, this characteristic and ornamental hybrid also seems worthy of a name and may be named $R$. Koehneana for E. Koehne, the author of Deutsche Dendrologie and many other important contributions to dendrology, who first listed it, though without description.

Prunus avium f. fastigiata (Poiteau), comb. nov.

Cerasus avium fastigiata Poiteau \& Turpin in Duhamel, Traité Arb. Fruit. 2: C. no. 5; t. 298, fasc. 50? [1828]. - Poiteau, Pomol. Franç. 1: 185, t. 298 (183846).

Prunus vel Cerasus avium pyramidalis Hort. ex Dippel, Handb. Laubh. 3:615 (1893), nom. altern.

Prunus avium lus. pyramidalis Ascherson \& Graebner, Syn. Mitteleur. Fl. 6,2: 152 (1906).

This form was first observed in the garden of $\mathrm{F}$. Cels near Paris in 1808 by Poiteau (1. c.), who describes it as a tree similar in habit to the Lombardy Poplar and bearing small yellow fruit. Whether Dippel's Prunus avium pyramidalis (l. c.) belongs here or represents another form of similar habit is doubtful, since he does not mention the color of the fruit and calls it a pyramidal form.

Prunus Vanioti H. Léveillé in Bull. Acad. Intern. Géog. Bot. 25: 45 (1915) "Prunus (Padus) Vanioti"; Cat. Pl. Yun-Nan, 234 (1917).

Prunus pubigera var. Prattii Koehne in Sargent, Pl. Wilson. 1: 67 (1911).

?Prunus pubigera var. longifolia Cardot in Notul. Syst. Herb. Mus. Hist. Nat. 4: 24 (1920).

?Prunus Ohwii Kanehira \& Hatusima in Kanehira, Formos. Trees, 270, fig. 220 (1936) ; in Trans. Nat. Hist. Soc. Formosa, 29: 156 (1939), pro syn. "P. Ohwi."

China. Szechuan: A. E. Pratt 94 (syntype of P. pubigera var. Prattii) ; R. P. Farges, distr. Tchen-keou-tin; E. H. Wilson 2845 (syntype of P. pubigera var. Prattii); C. Schneider 1284, 1286, 3534; W. P. Fang 4159, 7315; F. T. Wang 21122, 22865, 23302; T. T. Yӥ 530, 613. Kansu: J. F. Rock 14857, 14883. Hupeh: E. H. Wilson 181 and 2337 (syntypes of $P$. pubigera var. Prattii). Yunnan: J. $M$. Delavay, Ma-eul-chan, in 1891 (type of $P$. pubigera var. longifolia, not seen) ; $E$. $E$. Maire, Ma-Kong, in 1912 (Isoty pe of P. Vanioti); C. Schneider 2093, 3340; G. Forrest 19511, 21132, 23080; J.F. Rock 3409, 3578, 3649, 3995, 4025, 4461, 5758, 6782, 8305, $8838,10230,17200,23381$. Southeast Tibet: G. Forrest 19002; J. F. Rock 22084. Formosa: Ohwi 3591 (type of $P$. Ohwii, not seen).

Of the three varieties of $P$. pubigera (Schneid.) Koehne distinguished by Koehne, the var. Prattii is identical with P. Vanioti H. Lév., which is the correct name for $P$. pubigera, since the latter is invalidated by the earlier homonym $P$. pubigera Steudel. Thus $P$. pubigera var. Prattii represents the typical variety of $P$. Vanioti, and typical $P$. pubigera $(=P$. pubigera 
var. Potanini) becomes a variety of $P$. Vanioti. As the list of specimens cited above shows, typical $P$. Vanioti is the most widely distributed of the three varieties which have been distinguished. There can be little doubt that $P$. pubigera var. longifolia Cardot, judging from the brief description and the region where it was collected, belongs to typical $P$. Vanioti. As to the Formosan $P$. Ohwii Kanehira, the figure published by Kanehira agrees well with $P$. Vanioti and the identification of the species by Kanehira and Hatusima with $P$. pubigera also shows that $P$. Ohwii belongs with this affinity; its widely separated locality is not as strange as it may seem, for there are other plants known as occurring in Formosa and Yunnan, and not in the intervening region, of which the most striking example is perhaps Taiwania cryptomerioides Hay. (see Wilson in Jour. Arnold Arb. 7: 58. 1926).

Prunus Vanioti var. obovata (Koehne), comb. nov.

Prunus pubigera var. obovata Koehne in Sargent, Pl. Wilson. 1: 68, 196 (1911).Rehder \& Wilson in Sargent, Pl. Wilson. 3: 425 (1917).

China. Szechuan: E. H. Wilson 1045 (syntype), 4036, 4185, 3521 (Veitch Exp.). Hupeh: E. H. Wilson 186 (syntype). Chekiang: R. C. Ching 1385. Kiangsi: E. H. Wilson 1675.

This variety extends east to Chekiang and Kiangsi and is not found in Yunnan; it apparently represents the northeastern extension of the species.

Prunus Vanioti var. Potanini (Koehne), comb. nov.

Padus brachypoda (Batal.) Schneid. var. pubigera Schneider in Repert. Sp. Nov. Reg. Veg. 1: 70 (1905); Ill. Handb. Laubh. 1: 638 (1906).

Prunus pubigera Koehne in Verh. Bot. Ver. Brandenb. 52(1910): 106 (1911); in Sargent, Pl. Wilson. 1: 67 (1911), - Rehder in Jour. Arnold Arb. 13:320 (1932); Man. Cult. Trees Shrubs, ed. 2, 478 (1940). - Non Steudel (1841).

Prunus pubigera var. Potanini Koehne in Sargent, Pl. Wilson. 1:68 (1911), 196 (1912).

China. Szechuan: Southeast of Tachien-lu, E. H. Wilson 988, June and Sept. 1908 (syntype), 4133, Oct. 1910. Northern Tibet: River Pa-sin-kou (Pa-sengkou), above the village Tshzhumse (also spelled Tchumse?1), G. N. Potanin, July 1893 (SYNTYPE, not seen).

The area of this variety seems to be restricted to the extreme northwestern part of the range of the whole species and extends from the region near Tachien-lu to northeastern Tibet.

This variety, partly based on Potanin's specimen, includes the type of Prunus pubigera (Schneid.) Koehne, originally described as Padus brachypoda var. pubigera Schneider and based on Potanin's specimen which had been, according to Schneider, identified as Padus cornuta. When Koehne (l. c.) raised Schneider's variety to specific rank, he overlooked the older homonym of Steudel, Nomencl. Bot. ed. 2, 2: 404 (1841) based on Prunus pubescens Poiret, Encycl. Méth. Bot. Suppl. 4: 584 (1816), a later homonym of Pursh, Fl. Am. Sept. 1: 331 (1814). Poiret's name is validly published with a full description and the statement that the plant is cul-

${ }^{1}$ By Schneider, l. c. (1905) the name of the village is spelled Chusme, apparently a mistake or misprint; Komarov in his account of Potanin's travels (in Act. Hort. Petrop. 34(2): 359, 1928) spells it Tshzhumse. 
tivated in the Paris botanic garden and that its origin is unknown. It may be near or identical with $P$. maritima Marsh., which is mentioned by Poiret on p. 58 as $P$. sphaerocarpa Michx. with the synonym $P$. pubescens Pursh, but without seeing a specimen of Poiret's plant definite identification is not possible. In 1846 Heynhold, in his Nomencl. Bot. Hort. 2: 564, renamed Poiret's homonym P. Poiretiana.

Leguminosae subfam. Lotoideae (Luerssen), comb. nov.

Papilionaceae Scopoli, Fl. Carniol. 522 (1760, pref. Jun.). - Linnaeus, Philos. Bot. 37 (1763), nom. subnud. - Giseke, Praelect. Ord. Nat. Pl. 415 (1792). - Link, Handb. Erkenn. Gew. 2: 143 (1831). - Nom. Conserv. cf. Syn. Propos. Sixth Intern. Bot. Congr. 64 (1935) et Proc. Sixth Intern. Bot. Congr. 1:358 (1936).

Leguminosae ord. Papilionaceae R. Brown in Flinders, Voy. Terra Austral. 2(App.) : 552 (1814) "trib. Legum. ord. P."-De Candolle, Prodr. 2: 94 (1825) "subord."Lindley, Introd. Nat. Syst. Bot. 89 (1830) "trib." - Bentham \& Hooker f., Gen. Pl. 1: 437 (1867) "subord."

Fabaceae Reichenbach, Handb. Nat. Pflanzensyst. 227 (1837). - Small, Fl. Southeast. U. S. 593 (1903).

Leguminosae fam. Papilionatae A. Braun in Ascherson, Fl. Prov. Brandenb. 67 (1864) ; Ascherson, Verz. Phaner. Gefässkr. Berlin 35 (Fl. Prov. Brandenb. pt. 2) "Fam. P.," pref. 1859 (1864). - Taubert in Nat. Pflanzenfam. III. 3: 184 [1892].

Papilionaceae subfam. Lotoideae (p. 379), subfam. Hedysaroideae (p. 380), subfam. Vicioideae, subfam. Phaseoloideae (p. 381) Luerssen, Grundzüge Bot. 379-381 (1877).

Leguminosae subfam. Papilionoideae Robinson \& Fernald in Gray, Man. Bot. N. U. S. ed. 7, 500 (1908).

According to Art. 24 of the Rules of Botanical Nomenclature, names of subfamilies are taken from the names of one of the genera of the group with the ending -oideae. This excludes names of subfamilies such as Papilionaceae, Papilionatae and also Papilionoideae since they are not derived from the name of a genus of the group and the first two do not end in -oideae. Of the four subfamilies into which Luerssen divides the family Papilionaceae, forming in his arrangement together with the Mimosaceae and Caesalpiniaceae the order of Leguminosae, the name of the first and largest has been selected here as the name in an enlarged sense for the whole group considered by Luerssen as constituting the family Papilionaceae.

Adenocarpus decorticans Boissier in Bibl. Univ. Genève, n. sér. 13:40 (Notice Ab. Pinsapo, 9) (March, 1838) ; Elench. Pl. Nov. Hisp. 32 (1838) "in bibl. univ. gen. febr. 1836" sphalm. pro 1838; Voy. Bot. Esp. 145, t.41 (1839). - Willkomm \& Lange, Prodr. Fl. Hisp. 3: 462 [1877].

Adenocarpus Boissieri Webb, Iter. Hisp. 52 (1838).2

Owing to a misprint or lapsus calami in Boissier's Elenchus of June, 1838, the publication of Adenocarpus decorticans has always been quoted without exact citation as "febr. 1836" which is obviously an error; there is no article by Boissier in the Bibliothèque universelle de Genève for the year 1836, and moreover, at that time he had not yet discovered the species, since he did not start his voyage through Spain until April, 1837. The first description of the species appeared in the February issue for 1838 of the

\footnotetext{
2 Webb's synonym is only a renaming of Boissier's species, because he objected, for grammatical reasons, to the use of the present participle in the specific epithet.
} 
Bibliothèque universelle de Genève (nouv. sér. vol. 13) in a list of nineteen (nos. 1-18) new species appended to his "Description d'une nouvelle espèce de sapin du midi de l'Espagne" (op. cit. 401-410), in which Abies Pinsapo is described. This appended list has been omitted from the reprint which appeared under the title "Notice sur l'Abies Pinsapo" in Ann. Sci. Nat. Bot. sér. 2, 9: 167-172 (1838). The omission of this list of nineteen names of new species from the reprint in Ann. Sci. Nat. Bot. may have been one of the reasons that their original publication was overlooked in almost all cases and not given in Index Kewensis, where they are mostly credited to Boissier's Elenchus published about three months later with amplified descriptions and some changes, but without exact citation of their previous publication, only referred to as "bibl. bot. gen. (febr. 1838)." Apparently Boissier had sent the manuscript of his Elenchus to the printer before he had seen the February issue of 1838 of the Bibliothèque universelle de Genève; otherwise he certainly would have given the exact citation for his new species. As it seems important to make available the correct record of these overlooked names, they are given in their original sequence in the following list with the addition of the citation from his Elenchus and in some cases with other additional notes.

List of New species published by Boissier in the February issue of vol. 13 (1838) of Bibliothèque universelle de Genève

The citation of these species in his Elenchus reads "febr. 1838," which refers evidently to the February issue and not to the date of publication, since that issue contains on p. 426-427 meteorological observations up to February 28 and therefore could not have been published before March.

1. Abies Pinsapo Boissier in Bibl. Univ. Genève, nouv. sér. 13: 402, 406 (March 1838); Elench. 84 (June 1838).

2. Ranunculus acetosellaefolius Boissier in op. cit. 406 (March 1838); Elench. 5 (June 1838).

3. Vella spinosa Boissier in op. cit. 407 (1838); Elench. 14 (1838).

3. Alyssum longicaule Boissier in op. cit. 407 (1838) = Ptilotrichum longicaule Boissier, Elench. 13 (1838).

4. Lavatera oblongifolia Boissier in op. cit. 407 (1838); Elench. 24 (1838).

5. Adenocarpus decorticans Boissier in op. cit. 407 (1838); Elench. 32 (1838).

6. Adenocarpus grandiflorus Boissier in op. cit. 407 (1838); Elench. 32 (1838), pro syn. = A. Telonensis DC.

7. Genista versicolor Boissier in op. cit. 408 (1838); Elench. 31 (1838).

8. Anthyllis tejedensis Boissier in op. cit. 408 (1838); Elench. 35 (1838).

9. Leobordea lupinifolia Boissier in op. cit. 408 (1838); Elench. 36 (1838).

10. Geum heterocarpum Boissier in op. cit. 408 (1838); Elench. 40 (1838).

11. Saxifraga gemmulosa Boissier in op. cit. 409 (1838); Elench. 43 (1838).

12. Eryngium glaciale Boissier in op. cit. 409 (1838); Elench. 44 (1838).

13. Lonicera arborea Boissier in op. cit. 409 (1838); Elench. 55 (1838).

14. Artemisia granatensis Boissier in op. cit. 409 (March 1838); in De Candolle, Prodr. 7: 298 (April 1838); Elench. 60 (June 1838).

15. Gentiana Boryi Boissier in op. cit. 410 (1838); Elench. 65 (1838).

16. Sideritis glacialis Boissier in op. cit. $410(1838)=$ Sideritis scordioides var. vestita Boissier, Elench. 76 (1838).

17. Holcus caespitosus Boissier in op. cit. 410 (1838); Elench. 86 (1838). 
18. Festuca Lasto Boissier in op. cit. 410 (1838) ; Elench. 92 (1838) "febr. 1832" sphalm.; "loc. et nom. vulg. excluso" pro syn. =F. altissima Boissier, non Allioni $(1789)=F$. Boissieri Janka in Oester. Bot. Zeitschr. 14: 341 (1864) $=F$. drymea в. Boissieri Ascherson \& Graebner, Syn. Mitteleur. Fl. 2,1: 535 (1900).

Robinia leucantha, spec. nov.

Frutex ad $0.5 \mathrm{~m}$. altus, laxe ramosus, stolonifer, ramulis hornotinis glabris vel basin versus glandulis stipitatis et setis tenuibus sparse obsitis, annotinis et vetustioribus brunneis lenticellatis inermibus vel partim spinis stipularibus $1-3 \mathrm{~mm}$. rarius ad $1 \mathrm{~cm}$. longis et gracilibus armatis. Folia ab initio glaberrima vel errumpentia pilis sericeis caducis vestita mox glabra, 7-11-foliolata, vel in turionibus ad 15-foliolata; petioli $2-4 \mathrm{~cm}$. longi; foliola breviter petiolulata, ovali-ovata, 2-4 (rarius ad 6) $\mathrm{cm}$. longa et $1.2-2 \mathrm{~cm}$. lata, terminale interdum ad $3 \mathrm{~cm}$. lata, apice rotundata et emarginata vel obtusa, mucronulata, basi truncata, rarius late cuneata, in ramulis robustioribus oblongo-ovata et saepius acutiuscula, subtus pallida, venis utrinsecus 5-7, stipellis petiolulis subaequilongis. Racemi 2-5 (rarius ad 8) cm. longi, 3-6-flori, rarius ad 8- vel 10-flori; pedicelli 4-6 (rarius ad 10) $\mathrm{mm}$. longi, ut rhachis sparse glanduloso-setosi; calyx campanulatus, sparse glanduloso-pilosus et plus minusve puberulus vel villosulus, pallide viridis, apicem versus albescens, leviter bilabiatus, labio supero ad medium bifido, infero 3-lobato, lobis tubo subaequilongis 5-6 mm. longis triangulari-ovatis et plerumque longe acuminatis; corolla candida, ad $2.5 \mathrm{~cm}$. longa, vexillo rotundato circ. $2 \mathrm{~cm}$. diam. emarginato basi cordato, ungui $4-5 \mathrm{~mm}$. longo, alis inaequaliter obovatis $15 \mathrm{~mm}$. longis, auricula basali $2 \mathrm{~mm}$. longa, ungui $7 \mathrm{~mm}$. longo, carina $1.4 \mathrm{~mm}$. longa, ungui $7 \mathrm{~mm}$. longo; tubus staminalis $14 \mathrm{~mm}$. longus; stylus recurvatus, apicem versus villosus; ovarium leviter complanatum, dense stipitatoglandulosum. Fructus non visus.

Affinis $R$. nanae Elliott sed foliis et ramulis glabris, corolla candida facile diagnoscitur.

North America: Georgia: 6 miles west of Dahlonega and near Dahlonega and 4 miles west of Porter Springs, Lumpkin Co., W. W. Ashe, May 18, 1926 (4 specimens in W. W. Ashe Herb., Univ. N. Carol.). Cultrvated: Hort. W. W. Ashe, 1512 Park Ave., Washington, D. C., June 24, 1928 (sterile) and May 25, 1931, W. W. Ashe, W. W. Ashe Herb., Univ. N. Carol.) ; Kelsey Nursery, East Boxford, Mass., H. P. Kelsey, June 17, 1943; A. Rehder, June 18, 1945 (Herb. Arnold Arb., TYPE).

This new species seems to be most closely related to $R$. nana Elliott, which belongs to a group of shrubby species with glandular ovary and pink or rose-colored to purple flowers (Hispidae Rydb.); it differs strikingly from these species in its pure white flowers and from $R$. nana also in its glabrous leaves and branchlets. Judging from specimens in Ashe's herbarium, now at the University of North Carolina in Chapel Hill, kindly loaned to the writer by Prof. W. C. Coker, this species was first collected in Lumpkin Co., Georgia, by Ashe, who transplanted it to his garden in Washington and later sent a plant to Mr. Harlan P. Kelsey, suggesting that this new species might be named after him; he apparently overlooked the fact that there was already a Robinia Ashei described in 1923 by Schallert in Torreya. The epithet leucantha proposed here for this species is intended to call attention to the fact that white flowers are unusual in the 
group Hispidae, the only plant with white or partly white flowers referred to this group being $R$. albicans Ashe, which is apparently a hybrid of $R$. Pseudoacacia and R. Boyntoni Ashe. The possibility that the plant described above might also be a hybrid with $R$. Pseudoacacia is excluded by its low stoloniferous habit and the densely glandular ovary.

The description of this new species is based chiefly on the living specimens from the Kelsey nursery at East Boxford, Mass., where it has been growing since 1927. These specimens have the leaves and young branchlets quite glabrous from the beginning and the calyx sparingly stipitateglandular with the lower lobes long-acuminate and slightly longer than the tube; the branches are mostly unarmed or occasionally with short conical stipular spines. The specimens from Ashe's garden do not seem to be different, but the spontaneous specimens from Lumpkin County show some slight variation. The specimen from Porter Springs has the calyx rather densely villous and, like the rachis, lacking glandular-setose hairs, while the spines are slenderer and up to $5 \mathrm{~mm}$. long; one of the specimens collected six miles west of Dahlonega has the pubescence of the calyx and rachis similar to the preceding specimen and pedicels only about $4 \mathrm{~mm}$. long, while the other specimen has the calyx and rachis sparingly glandular-setose, the pedicels up to $10 \mathrm{~mm}$. long, and the unfolding leaves silky-pubescent but soon becoming quite glabrous; the specimen from near Dahlonega has the unfolding leaves pubescent like the preceding, the calyx rather densely villous and almost without glandular setae, the rachis sparsely glandularsetose, and slender spines up to $10 \mathrm{~mm}$. long. The flowers of all these specimens are apparently white, but on the labels there is no reference to the color of the flowers nor to the habit of the plants. As the differences between the several specimens are only slight and more or less intergrading, and as all the specimens are from a rather restricted area, they must be considered conspecific, representing an otherwise well defined species.

Vitis quinquangularis, nom. nov.

Vitis pentagona Diels \& Gilg in Bot. Jahrb. 29:460 (1900). - Rehder in Sargent,

Pl. Wilson. 3: 428 (1917). - Non Voigt (1845), nec M. A. Lawson (1875).

Vitis Coignetiae sensu Diels in Bot. Jahrb. 29: 461 (1900), non Planchon (1883).

Vitis ficifolia var. pentagona Pampanini in Nuov. Giorn. Bot. Ital. 17:116 (1910).

Vitis quinquangularis var. bellula (Rehder), comb. nov.

Vitis pentagona var. bellula Rehder in Sargent, Pl. Wilson. 3: 428 (1917).

As the name Vitis pentagona is preoccupied by two earlier homonyms, namely Vitis pentagona (Roxb.) Voigt, Hort. Suburb. Calcutt. 28 (1845), based on Cissus pentagona Roxburgh, Fl. Ind. 426 (1820), and V.pentagona Lawson in Hooker f., Fl. Brit. Ind. 1: 646 (1875), it must receive a new name, for which the Latin translation of its Greek epithet has been chosen.

Rhododendron trichanthum, nom. nov.

Rhododendron villosum Hemsley \& Wilson in Kew Bull. 1910: 119 (1910). - Hutchinson in Rhododendron Soc., Spec. Rhodod. 770 (1930). - Non Roth (1807).

It seems to have been hitherto overlooked that $R h$. villosum Hemsl. \& Wils. is invalidated by an older homonym, namely $R h$. villosum $\mathrm{A}$. W. Roth, 


\section{$2 \mathrm{BHL}$ Biodiversity Heritage Library}

Rehder, Alfred. 1945. "Notes on Some Cultivated Trees and Shrubs, II." Journal of the Arnold Arboretum 26(4), 472-481. https://doi.org/10.5962/bhl.part.13126

View This Item Online: https://www.biodiversitylibrary.org/item/33602

DOI: https://doi.org/10.5962/bhl.part.13126

Permalink: https://www.biodiversitylibrary.org/partpdf/13126

\section{Holding Institution}

Missouri Botanical Garden, Peter H. Raven Library

\section{Sponsored by}

Missouri Botanical Garden

\section{Copyright \& Reuse}

Copyright Status: In copyright. Digitized with the permission of the rights holder.

Rights Holder: Arnold Arboretum of Harvard University

License: http://creativecommons.org/licenses/by-nc-sa/3.0/

Rights: https://biodiversitylibrary.org/permissions

This document was created from content at the Biodiversity Heritage Library, the world's largest open access digital library for biodiversity literature and archives. Visit BHL at https://www.biodiversitylibrary.org. 